\title{
PROTECTION OF WHISTLEBLOWERS BY THE EUROPEAN UNION, THE COUNCIL OF EUROPE, AND THE EUROPEAN COURT OF HUMAN RIGHTS / Sára Kiššová
}

\author{
Mgr. Sára Kiššová \\ PhD. Student \\ Comenius University in Bratislava \\ Faculty of Law \\ Šafárikovo nám. č. 6 \\ 81000 Bratislava \\ Slovakia \\ sara.kissova@flaw.uniba.sk \\ ORCID: 0000-0003-2834-8853
}

Submitted: 17 November 2021 Accepted: 17 December 2021 Published: 31 December 2021

\begin{abstract}
Whistleblower protection in the European Union is undergoing significant developments. The new Directive (EU) 2019/1937 of the European Parliament and of the Council of 23 October 2019 on the protection of persons reporting breaches of Union law sets a minimum standard for the protection of whistleblowers. It is awaiting implementation in Member States' national law by December 2021. However, a certain level of protection is also guaranteed by the European Court of Human Rights case law principles. Reports of illegal activities provided from close internal sources can strengthen the protection of the EU's financial interests. Adequate protection is needed to prevent retaliation against whistleblowers. As the deadline for transposing this directive approaches, the article aims to analyse the Directive 2019/1973 and compare it with the protection guaranteed by Article 10 of the European Convention on Human Rights.
\end{abstract}

Key words: Whistleblowing; whistleblower; Article 10; ECHR; ECtHR; Directive 2019/1937

Suggested citation:

Kiššová, S. (2021). Protection of Whistleblowers by the European Union, the Council of Europe, and the European Court of Human Rights. Slovak Yearbook of European Union Law, vol. 1, 25-36. https://doi.org/10.54869/syeul.2021.1.267

\section{INTRODUCTION}

The role of the European Union ("EU") in controlling the budget is to ensure that the EU budget is used correctly, to protect the Union's financial interests, and to combat fraud. Beginning with the creation of the "Anti-Fraud Coordination Unit" working group in July 1988, which was later renamed OLAF," a body with complete independence in internal and external investigations was set up (Committee of Independent Experts, 1999, pp. 9-10). From a legislative point of view, it was the Convention on the protection of the European Communities' financial interests, introduced in October 2002 by the Council Act of 26 July 1995, drawing up the Convention on the protection of the European Communities' financial interests. In addition, several secondary pieces of legislation have been introduced in recent years to increase the protection of the EU's financial interests. ${ }^{2}$ The establishment of the European Public Prosecutor's Office (EPPO), through enhanced cooperation, provides for a system of shared competences between the EPPO and national authorities in the fight against criminal offenses affecting the financial interests

\footnotetext{
1 June 1999.

${ }^{2}$ For example: Establishing enhanced cooperation in setting up a European Public Prosecutor's Office.
} 
of the Union. ${ }^{3}$ This cooperation certainly strengthens the protection of the EU's financial interests, and we will be able to examine its possible effectiveness in the near future. In addition, negotiators of the Council of the EU and the European Parliament (EP) reached an agreement at the end of 2020 on a new general conditionality regime to protect the EU budget in response to concessions from the individual Member States (Council, 2020). From this point of view, it can be said that the EU has made progress in creating mechanisms to protect its financial interests.

However, it is also necessary to look at the protection of the European Union's financial interests from a non-institutional point of view, referring to staff who could be in contact or work with the Union's finances. Most of the Union's funds are managed in the beneficiary's country of origin, so it is up to national governments to ensure that they are appropriately spent. At the national level, each Member State has a system of protection for EU funds, whether it is a well-established administrative control procedure or effective channels for criminal investigations. However, until the year 2019, the EU and the many Member States lacked one essential part of the system of non-institutional protection, namely the protection of whistleblowers (Nielsen, 2013). Things have only moved in 2017 as open public consultations (see European Commission, 2017) have taken place after several revelations of whistleblowers. ${ }^{4}$ All this led to the fact that in April 2018, a directive on the protection of whistleblowers was proposed and later adopted in October 2019. ${ }^{5}$ Directive (EU) 2019/1937 of the European Parliament and of the Council of 23 October 2019 on the protection of whistleblowers ("the EU Whistleblowers Directive") entered into force in December 2019, and its implementation period ends in December 2021.

Until then, the only protection guaranteed at the European level to whistleblowers (besides countries having some sort of such protection) is provided by Article 10 of the European Convention on Human Rights (the Convention) and the principles established by the case-law of the European Court of Human Rights (ECtHR).

For these reasons, this article aims to analyse the current protection of whistleblowers at the European Union level by analyzing and synthesizing available sources. The available literature, which deals with the issue, the EU legislature, the ECtHR case-law, and the sources devoted to Article 10 of the Convention will be analysed. The analysis should result in an assessment of whether the protection of whistleblowers at the Union level will be sufficient after the transposition of the EU Whistleblowers Directive and whether the transposition of the EU Whistleblowers Directive into national law will provide protection similar to that guaranteed by the ECtHR.

\section{PROTECTION OF WHISTLEBLOWERS AT THE EUROPEAN LEVEL: THE EUROPEAN CONVENTION ON HUMAN RIGHTS AND THE COUNCIL OF EUROPE DOCUMENTS}

Whistleblowing is a mechanism by which an employee, whether in the public or private sphere, becomes aware of a breach of the law that undermines a public interest that would not have been disclosed without such notification to the competent authorities. However, for a notification to be made, a whistleblower must be protected from possible sanction/retaliation by the employer. Until the EU Whistleblower Directive

\footnotetext{
313 recital of Council Regulation (EU) 2017/1939 of 12 October 2017 implementing enhanced cooperation for the establishment of the European Public Prosecutor's Office.

${ }^{4}$ For example the Volkswagen emissions scandal in 2015 or Lux Leaks at the end of 2014.

${ }^{5}$ Directive (EU) 2019/1937 of the European Parliament and of the Council of 23 October 2019 on the protection of persons who report breaches of Union law.
} 
is implemented, a whistleblower is protected through Article 10 of the ECHR on freedom of expression in each Member State, unless a Member State has established its national protection. However, the applicable principles of the ECtHR case law are the only way for whistleblowers in several Member States to achieve justice. Therefore, the following text will address the freedom of expression enshrined in Article 10 of the Convention and how the Council of Europe influences and creates the protection of whistleblowers in Europe (see also Andreis, 2019).

\subsection{Article 10 of the European Convention on Human Rights}

As the ECtHR ruled in Handyside v. the United Kingdom, freedom of expression is one of the fundamental pillars of a democratic society and one of the fundamental conditions for its progress and the development of every human being. ${ }^{6}$ Professor Svák also describes freedom of speech as "a person's desire to present his identity" while at the same time having many meanings associated with the self-realization of man (2019, p. 234). Within the framework of freedom of speech, we can promote our political, cultural, or religious views through an increasing number of information channels. However, this freedom has a much greater impact than it seems at first glance.

There are many divisions within the subjects of speech. However, within this article, subjects according to social status are relevant: journalists, nongovernmental organizations, civil servants, armed forces, judges, lawyers, and doctors. ${ }^{7}$ Within this division, the relevant entity is the civil servants within whom the notion of whistleblowing originally appeared. It is a conflict of loyalty with the obligation to inform about illegal activity in the civil service. It was the case of Tierbefrierer and others v. Germany ${ }^{8}$ where the ECtHR moved the protection of freedom of expression to the horizontal private sphere and granted the protection of freedom of expression to a whistleblower from the private sphere (Svák, 2019, p. 265). The ECtHR, therefore, derives several freedoms from Article 10 of the Convention. It includes the freedom to disseminate and receive information and ideas as well as the freedom of the press. The scope of article 10 of the Convention has gradually extended to whistleblowing in the workplace, ${ }^{9}$ and its protection applies to public and private workers (Svák, 2019, pp. 263-266).

However, freedom of speech has its limits. According to Article 10(2) of the Convention, the exercise of the right to freedom of expression carries duties and responsibilities and may therefore be subject to certain restrictions. Interference with freedom of expression can only occur if three cumulative conditions are met. The Court assesses whether the intervention is (1) prescribed by law, (2) pursues a legitimate aim, and (3) is necessary in a democratic society (Svák, 2019, p. 115). With regard to whistleblowing, the ECtHR, in examining the fulfilment of conditions, focuses mainly on the fulfilment of the last, third condition - whether the intervention was necessary in a democratic society (Yurttagül, 2021, p.115).

\footnotetext{
${ }^{6}$ ECtHR, Handyside v. the United Kingdom, app. no. 5493/72, 7 December 1976, para. 49.

7 Ibid., p. 253.

${ }^{8}$ ECtHR, Tierbefreier and others v. Germany, app. no. 45192/09, 16 January 2014.

${ }^{9}$ ECtHR, Guja v. Moldova [GC], app. no. 14277/04, 12 February 2008, para. 52; ECtHR, Kudeshkina v. Russia, app. no. 29492/05, 26 February 2009, para. 85; ECtHR, Herbai v. Hungary, app no. 11608/15, 5 November 2019, para. 36; ECtHR, Soares v. Portugal, app. no. 79972/12, 21 June 2016, para. 39 and more.
} 


\subsection{The Council of Europe and the Protection of Whistleblowers}

Several reports have been issued at the Council of Europe level on whistleblower protection in the Member States. Since 1990, the Council of Europe has taken steps to protect whistleblowers as an action plan against corruption (Multidisciplinary Group on Corruption, 1996). As part of this action plan, the Council of Europe declared that corruption significantly undermined the fundamental values on which our society is built. Its steps subsequently led to the adoption of two essential documents in 1999: the Criminal Law Convention on Corruption ${ }^{10}$ and the Civil Law Convention on Corruption. ${ }^{11}$

In 2009, the report was issued by the Council of Europe's Committee on Legal Affairs and Human Rights (Committee on Legal Affairs and Human Rights, 2009) which pointed out the diversity of rules on the protection of whistleblowers in the Council of Europe's Member States. Resolution 1729 (2010) is considered the first step towards common standards for the protection of whistleblowers in Europe. Through it, the Council of Europe called on all Member States to review their legislation on the protection of whistleblowers, pointing out certain fundamental principles they should incorporate into legal orders (see Council of Europe, 2014, p. 16, 20 et seq). Parliamentary Assembly Resolution 1729 (2010) and Recommendation 1916 (2010) offer the Member States several guiding principles which should be incorporated into national law. Among the principles is defined, inter alia, the need to determine protected reports in good faith before various types of retaliation. It also defines who should be protected by this legislation, emphasizing public and private sector workers. In individual areas of law, protection against unfair dismissal is recommended in labour law, and protection against criminal prosecution for defamation or breaking of official or commercial secrecy is recommended in criminal law. The later adopted Recommendation of the Committee of Ministers CM / Rec (2014) 7 on the protection of whistleblowers, adopted on 30 April 2014, aimed to guide member States in reviewing their national rules on the protection of whistleblowers or in creating such rules.

\subsection{The Case Law of the European Court of Human Rights - The Protection of Whistleblowers}

In the context of the protection of human rights and thus the protection of whistleblower rights at the European level, it is necessary to look into the European Court of Human Rights decision-making practice. The Court has taken a few crucial decisions concerning whistleblower reporting, which set out the key principles to be applied when assessing the right to freedom of expression enshrined in Article 10 of the Convention. In its case law, the ECtHR determines the scope of protection of whistleblowers and the conditions for providing protection under Article 10 of the Convention.

As regards the scope of protection guaranteed by Article 10 of the Convention and the ECtHR, its decision-making process, the ECtHR dealt with cases where a violation of Article 10 of the Convention was sought by persons working in the state sphere, ${ }^{12}$ at the same time, the ECtHR also granted protection between employer and employee relations, which were governed by private law rules. ${ }^{13}$ Therefore, in material terms, the

\footnotetext{
${ }^{10}$ Criminal Law Convention on Corruption no. 173 of 1 July 2002.

${ }^{11}$ Civil Law Convention on Corruption of the Council of Europe no. 174 of 1 November 2003.

${ }^{12}$ ECtHR, Guja v. Moldova [GC], app. no. 14277/04, 12 February 2008, para. 52; ECtHR, Vogt v. Germany [GC], app no. 17851/91, 26 September 1995, para. 53.

${ }^{13}$ ECtHR, Heinisch v. Germany, app no. 28274/08, 21 July 2011, para. 44
} 
protection of whistleblowers is not materially limited, and the Court has provided protection to whistleblowers in various (labor) areas. ${ }^{14}$

\subsubsection{Guja v. Moldova - Six Criteria}

One of the most significant cases before the ECtHR is Guja v. Moldova, in which the Court identified six basic criteria for assessing proportionality to whistleblower's freedom of expression interference, ruling that Moldova violated Article 10 of the Convention by firing a civil servant disclosing public interest information politicians about influencing the judiciary.

In 2002, criminal proceedings were instituted against four police officers accused of ill-treatment and illegal detention of ten people suspected of parliamentary election crimes. ${ }^{15}$ Following the opening of the proceedings, the four officers wrote to the President, the Prime Minister, and the Deputy Speaker of Parliament requesting protection from prosecution. Shortly afterward, the President issued a public statement calling on law enforcement to ignore any attempts by public officials to put pressure on them. ${ }^{16}$ As a result, criminal proceedings against the nationals were stopped, and a few days after the President made his statements, lacob Guja, then head of the General Prosecutor's Office's press department, presented two non-confidential letters written by the vice-president and deputy interior minister to the newspaper Jurnal de Chisinau. ${ }^{17}$ One of the letters spoke of the effective release of one of the accused police officers. On 31 January 2003, the Jurnal de Chisinau took photographs of the two letters, together with an article alleging that the Vice-President of Parliament had intimidated prosecutors and protected four police officers. ${ }^{18}$ After hearing the Prosecutor General regarding the origin of the letters, Mr. Guja commented that he had sent them to combat the abuse of influence. As a result, Mr. Guja and the prosecutor suspected of providing letters to Mr. Guja have been dismissed. ${ }^{19}$

Mr. Guja claimed, inter alia, that the letters were not classified as secret under the law, that he was therefore not required to consult with the heads of other departments before contacting the press, and that his release violated his right to freedom of expression. ${ }^{20}$ As a result, the Chisinau Court of Appeal dismissed the lawsuit, ${ }^{21}$ and the Supreme Court upheld the decision on appeal, arguing that obtaining information by abusing a person's status was not part of freedom of expression. ${ }^{22}$

Mr. Guja, therefore, turned to the ECtHR, arguing that his release for publishing the contested letters had violated his right to freedom of expression and, in particular, his right to disseminate information and ideas to third parties under Article 10 of the Convention. ${ }^{23}$ Therefore, according to Mr. Guja, the publication of the letters had to be

\footnotetext{
14 See for instance: ECtHR, Bucur and Toma v. Romania, app. no. 40238/02, 8 January 2013; ECtHR, Marchenko v. Ukraine, app. no. 4063/04, 19 February 2009; ECtHR, Soares v. Portugal, app. no. 79972/12, 21 June 2016

${ }^{15}$ ECtHR, Guja v. Moldova [GC], app. no. 14277/04, 12 February 2008, para. 9.

16 Ibid., para. 11.

17 Ibid., para. 13.

18 Ibid., para. 15.

19 Ibid., paras. 19 and 21

20 Ibid., para. 22.

21 Ibid., para. 23

22 Ibid., para. 25

23 Ibid., para. 48.
} 
regarded as a notification of an infringement, ${ }^{24}$ claiming that he had acted in good faith and was convinced that the information disclosed concerned the commission of a serious crime by the Vice-President of Parliament for corruption and "trafficking in influence." ${ }^{25}$ Furthermore, the Government argued that since the letters were internal documents that Mr. Guja would not commonly have accessed based on his function, it should therefore be understood that Mr. Guja has stolen this information. ${ }^{26}$

In assessing this case, the Court monitored the fulfilment of the six criteria that must be met for the whistleblower to be protected. First, the published information should be in the public interest and second, at the same time, its authenticity. ${ }^{27}$ Third, the channels of disclosure should be respected. ${ }^{28}$ The Court examines the whistleblower's ability to report these proceedings before making this information public. Therefore, disclosure of information should be made in the first instance to the superior or, if possible, to the competent authority or body. Thus, it can be said that the whistleblower should prioritize reporting violations internally (European Court of Human Rights, 2020, p. 67, para 362). Whistleblowers should therefore report to the competent authorities if internal channels do not respond, and they should only go public as a last resort, i.e. if the previous two steps were unsuccessful (the channel did not respond to the report). Fourth, the whistleblower should act in good faith, and his reporting should not be motivated by goals such as personal or economic gain. ${ }^{29}$ Fifth, the Court assesses the damage suffered by the employer and examines whether the public interest in obtaining information balances it. ${ }^{30}$ Sixth, the ECtHR examines the severity of the sanction imposed on a whistleblower and its consequences.

\section{THE EU WHISTLEBLOWERS DIRECTIVE AND ITS MAIN ELEMENTS}

Until 2019, at the level of the European Union, there was no legislation governing the protection of whistleblowers. Protection has been (and still is until the end of the transposition period of December 2021) left in the hands of the Member States and, as mentioned above, guaranteed by Article 10 of the Convention and the principles of the ECtHR. However, the path to the ECtHR is relatively complex, and there is a need for a potential whistleblower to be protected from the moment of his decision to report illegal activity. Several EU countries either have absent legislation in this area at the national level or relatively weak existing legislation. For these reasons, the EU has decided to create a basic level of protection, however, the Union's financial interests remain the main object of protection in this case.

The new Directive (EU) 2019/1937 of the European Parliament and the Council of 23 October 2019 on the protection of persons who report breaches of Union law provides a basic harmonizing framework for protection. As with other legislation, it is possible to note certain advantages and disadvantages of this directive. In the following sections, the EU Whistleblower Directive will be analysed. I will focus mainly on three elements of the legislation: the scope of the directive, the conditions for the protection to

\footnotetext{
${ }^{24}$ Ibid., para. 60.

25 Ibid., para. 61.

${ }^{26}$ Ibid., para. 64.

27 Ibid., para. 77.

${ }^{28}$ Ibid., para. 73.

29 Ibid., para. 77.

30 lbid., paras. 74-76.
} 
be granted, and reporting channels. I chose these elements because of the need to compare them with the protection guaranteed by ECtHR.

\subsection{Scope of the EU Whistleblower Directive}

The material scope of the EU Whistleblower Directive is relatively narrow, as it applies only to breaches of EU law or to areas of EU competence. ${ }^{31}$ These include public procurement, consumer protection, and, above all, infringements that harm the Union's financial interests. ${ }^{32}$

In its personal scope, the EU Whistleblower Directive applies to whistleblowers in the private and public sectors, including persons with worker status within the meaning of Article 45(1) TFEU, civil servants, and persons with the status of self-employed persons who carry out activities within the meaning of Article 49 TFEU. ${ }^{33}$ Furthermore, this directive shall also apply to shareholders and persons belonging to administrative, management, supervisory bodies, trainees, and volunteers. ${ }^{34}$ Interestingly, protection should also apply to persons whose employment relationship has yet to begin, i.e., a person in a pre-contractual relationship, if he has become aware of the infringements/illegal activities at this stage..$^{35}$ In addition, the EU Whistleblower Directive protects intermediaries or third parties who are associated with the reporting person (colleagues, relatives), as well as legal entities that the reporting persons own, work for, or are otherwise connected within a work-related context. ${ }^{36}$

\subsection{Conditions for the Protection}

The EU Whistleblower Directive does not establish any condition for the protection to be granted. Neither good faith is not necessary to provide when reporting a breach. Therefore, courts of the member states will not examine such a condition.

\subsection{Reporting Channels}

If an employee discovers certain irregularities in the course of his work, such as mismanagement of EU funds, he must have enough channels to report if he decides so. The EU Whistleblower Directive sets out three reporting levels to create a hierarchy between internal and external reporting and sets the timeframe for feedback. Under the directive, Member States encourage whistleblowers to report through internal reporting channels and use external channels if the whistleblower considers a risk of retaliation. In addition, public publication/publication after internal and external announcements can be made after certain conditions are met. The directive allows a whistleblower to go public as a first step if it fulfils the conditions for a reasonable suspicion that the infringement may constitute an immediate or manifest danger to the public interest, for example, in

\footnotetext{
${ }^{31}$ Art. 5 (1), (i) and (ii) of Directive (EU) 2019/1937 of the European Parliament and of the Council of 23 October 2019 on the protection of persons who report breaches of Union law.

32 See: Annex no. I of Directive (EU) 2019/1937 of the European Parliament and of the Council of 23 October 2019 on the protection of persons who report breaches of Union law.

${ }^{33}$ Art. 4 (1), (a) and (b) of Directive (EU) 2019/1937 of the European Parliament and of the Council of 23 October 2019 on the protection of persons who report breaches of Union law.

34 Ibid., Article 4 (1), (c).

35 Ibid., Art. 4 (3).

36 Ibid., Art. 4 (4).
} 
the event of an emergency or the risk of irreversible damage or the risk of retaliation in the event of an external report.

\section{COMPARISON OF THE EU WHISTLEBLOWER DIRECTIVE WITH THE PROTECTION GUARANTEED BY THE ECTHR}

In the last part of this article, we will compare the different levels of protection for whistleblowers, comparing the protection provided by the EU Whistleblower Directive with the protection guaranteed by the ECtHR. I will therefore focus on the differences that I noticed during the analysis and describe them briefly.

\subsection{Scope}

First, I will focus on the differences in the material and personal scope of both levels of protection. In its material scope, the EU Whistleblower Directive is relatively narrow as it only applies to breaches of EU law or areas of EU competence, precisely to the protection of the financial interest of the EU. Nevertheless, protection under the principles of the ECtHR is not materially limited, and the ECtHR has granted protection to various kinds of whistleblowers in different areas with dissimilar facts of the case, provided that the whistleblower procedure has passed the test of the six criteria mentioned above.

The European Union is therefore not seeking to create general protection of whistleblowers and their freedom of expression, but it aims to protect the Union's financial interests through the directive in question. The mere fact that the material content is aimed solely at the financial interests of the Union cannot be blamed on the Union. However, it is also worth considering some of the disadvantages of such a delimitation: when the EU Whistleblower Directive is incorporated into national law, protection of whistleblowers will be de facto guaranteed only in relation to proceedings against the interests of the Union. A whistleblower may thus find himself in a situation where he is unsure whether he is reporting an infringement related to the interests of the Union, which may deter him from reporting. Of course, this statement is only relevant in the case of a scenario if a Member State transposes into its legislation only the framework required by the directive.

In the context of the personal scope, the directive is very detailed and provides a minimum standard of protection for a wide range of exhaustively appointed entities. At the same time, the ECtHR divides these entities only vertically and horizontally thus does not provide an exhaustive list of subjects. Moreover, in its decision-making, the ECtHR dealt with cases where there was a violation of Article 10 of the Convention and protection was exercised by persons working in the state sphere. Still, at the same time, it also granted protection to the relations between the employer and the employee, which were governed by private law norms.

\subsection{Conditions for the Protection}

Another aspect that will be compared is the conditions that must be satisfied for the protection to be granted. The motive of the reporting whistleblower is to be one of the factors examined by the ECtHR, and at the same time, the report cannot be motivated by personal guilt or intolerance (European Court of Human Rights, 2020, p. 65). In addition, it should not be done in order to obtain personal benefits, including monetary benefits. Furthermore, the ECtHR focuses on the authenticity of the information published/reported and therefore tests this factor. The ECtHR examines whether the 
whistleblower has borne the burden of freedom of expression and whether he has verified that information in terms of accuracy and reliability.

On the other hand, the EU Whistleblower Directive defines "breach information" as information, including reasonable suspicions of actual or potential breaches that occur or are very likely to occur in the organization where the notifier works or has worked. The directive, therefore, reduces the requirements for the verification of information and its accuracy to such a level that it is sufficient to protect a whistleblower, which cannot be viewed as the right direction to take in today's society. The reputation of companies, government agencies, and those responsible for them is at stake.

Therefore, it is necessary to reconsider whether the whistleblower's protection should be set so that a whistleblower has minimal to zero liability for incorrect reporting or publication. Furthermore, in my opinion, it is necessary to reconsider whether a condition of good faith and the authenticity of information should be part of the directive as a guarantee against fraudulent, fouled reports, which will otherwise ultimately only burden the reporting system set up by the Member States.

\subsection{Reporting Channels}

As I mentioned earlier, a whistleblower has to have sufficient channels to report actions that seem to breach law. In making its decision, the ECtHR examines the possibility of the whistleblower notifying such actions before deciding to disclose this information. Therefore, disclosure should be made in the first instance to the superior or, if possible, to the competent authority or authority. The ECtHR thus operates on a two-tier model of disclosure channels, as it maintains internal and external reporting at the same (first) level. As a last resort, information may be made available to the public only if it is manifestly impracticable. Therefore, the Court must examine whether the applicant had other effective means of reporting at his disposal.

The EU Whistleblower Directive introduces a slightly different approach but is still essentially governed by the case law of the ECtHR. However, unlike the ECtHR procedure, the directive allows a whistleblower to use the public publication as a first step if it fulfills the conditions for a reasonable suspicion that the infringement may constitute an immediate or manifest danger to the public interest, for example, in the event of an emergency or the risk of irreversible damage or the threat of retaliation in the event of an external report. The directive, therefore, simplifies the public publication of published information, which is effective when EU funds are primarily in the hands of public authorities, so there could be a risk of failure of external investigations.

\section{CONCLUSION}

Whistleblowers undoubtedly help detect illegal activity, which can constitute a criminal offense. Therefore, their protection against retaliation is very important, and it is appropriate that it be guaranteed at the European Union level in every Member State. However, it is questionable how the individual Member States will create the final national legislation. An analysis of the objectives set has shown that protection at the European level is more general than that proposed by the EU Whistleblowers Directive. The biggest stumbling block in the European Union's legislation is its material scope. While the European level does not materially limit protection, the EU creates legislation that sets only a minimum protection standard. The directive only provides for substantive scope for notifications concerning EU matters, and the Member States do not have to extend the substantive scope in their legislation. 
Protecting the EU's financial interests through whistleblowers has great potential if the EU Whistleblower Directive is sufficiently implemented in national law. However, there is a strong need for the Member States to extend protection under their national legislation to as many areas as possible and to implement the directive in a 1: 1 ratio, i.e., only to proceedings related to EU finances. The EU Whistleblower Directive sets a minimum standard for whistleblowers and, in a way, complements the protection guaranteed by Art. 10 of the Convention. However, the EU must ensure that a potential whistleblower is not afraid to report infringements solely because he is unsure whether the violation falls within EU law or is outside that scope. The directive gives Member States and employers the obligation to establish external and internal channels to facilitate the reporting of infringements, which is a positive element. However, it is questionable how the reduced requirement for verification of reported information (in the directive, suspicion is sufficient) compared to the requirement set by the ECtHR principles will impact practice. We will soon monitor how the Member States have adapted their whistleblower legislation after December 2021.

\section{BIBLIOGRAPHY}

Andreis, E. (2019). Towards Common Minimum Standards for Whistleblower Protection across the EU. European Papers, 4(2), pp. 575-588. DOI: 10.15166/2499$8249 / 315$.

Svák, J. (2019). Nadnárodné systémy ochrany l'udských práv. (Prvý zväzok), Štruktúra systémov a ochrana politických práv. Bratislava: Wolters Kluwer. ISBN: 978-808168-971-0.

Yurttagül, H. (2021). Whistleblower Protection by the Council of Europe, the European Court of Human Rights and the European Union. An Emerging Consensus. Cham: Springer. ISBN: 978-3-030-78058-6.

Committee of Independent Experts (1999). Second Report on Reform of the Commission. Analysis of current practice and proposals for tracking mismanagement, irregularities and fraud, Volume 1.

Committee on Legal Affairs and Human Rights of the Council of Europe (2009). Report on the protection of "whistleblowers", doc. 12006, avaliable at: http://assembly.coe.int/nw/xml/XRef/Xref-XML2HTML-en.asp?fileid=12302 (accesed on: 10.12.2021).

Council of Europe (2014). Recommendation CM/Rec(2014)7 and explanatory memorandum. Council of Europe, avaliable at: https://rm.coe.int/16807096c7 (accesed on: 10.12.2021).

Council of the EU (2020). Budget conditionality: Council presidency and Parliament's negotiators reached a provisional agreement. Avaliable at: https://www.consilium.europa.eu/en/press/press-releases/2020/11/05/budgetconditionality-council-presidency-and-parliament-s-negotiators-reachprovisional-agreement/ (accesed on 10.12.2021).

European Commission (2017). Public consultation on whistleblower protection, avaliable at: https://ec.europa.eu/newsroom/just/items/54254/en (accesed on 10.12.2021).

European Court of Human Rights (2020). Guide on Article 10 of the European Convention on Human Rights, Freedom of expression. First Edition. Avaliable at: https://www.echr.coe.int/documents/guide_art_10_eng.pdf (accesed on 10.12.2021). 
Multidisciplinary Group on Corruption (GMC) (1996). Programme of action against Corruption, GMC (96) 95, avaliable at:

https://rm.coe.int/CoERMPublicCommonSearchServices/DisplayDCTMContent? documentld=09000016806ccfb6 (accesed on 10.12.2021).

Nielsen, N. (2013). EU-Wide whistleblower protection law rejected. EU Observer, 23 October 2013, avaliable at: https://euobserver.com/justice/121873 (accesed on 10.12.2021).

Council of Europe (2003). Civil Law Convention on Corruption of the Council of Europe no. 174 of 1 November 2003.

Council Regulation (EU) 2017/1939 of 12 October 2017 implementing enhanced cooperation on the establishment of the European Public Prosecutor's Office ('the EPPO').

Criminal Law Convention on Corruption, No. 173 of 1 July 2002.

Directive (EU) 2019/1937 of the European Parliament and of the Council of 23 October 2019 on the protection of persons who report breaches of Union law.

European Convention on Human Rights.

ECtHR, Bucur and Toma v. Romanian, app. no.40238/02, 8 January 2013.

ECtHR, Marchenko v. Ukraine, app. no. 4063/04,19 February 2009.

ECtHR, Soares v Portugal, app. no. 79972/12, 21 June 2016.

ECtHR, Vogt v. Germany [GC], app. no. 17851/91, 26 September 1995.

ECtHR, Guja v. Moldova [GC], app. no. 14277/04, 12 February 2008.

ECtHR, Heinisch v. Germany, app. no. 28274/08, 21 July 2011.

ECtHR, Herbai v. Hungary, app. no. 11608/15, 5 November 2019.

ECtHR, Kudeshkina v. app. 29492/05, 26 February 2009.

ECtHR, Tierbefreier and Others v. Germany, app. no. 45192/09 09, 16 January 2014. 
